have been an offshoot from the tribe, which, under the names of Kata or Taka, Kāthya or Thākya, with other variants, was once very powerful in the north and west of India.

Both Katas and Katurias were of Solar race: they both claimed descent from the Nāga demigod Bāsdeo, Bāska Nāg, or Vāsuki; and both had for their tribal emblem the Nàga or hooded serpent. At Badariwār, in the Panjāb Himālaya, are temples to Bāsdeo, the deified ancestor of the Katas or Takas; and near the holy Badarinath is an ancient temple to Bāsdeo, the ancestor of the Katuria răjas.

One of the Katurias is said to have been a powerful supporter of Sankara Achärya, who, with the aid of this chief, founded the present Badarinatth temple, and brought the priests from the Dakhan.

All ancient remains in Kamāon and Garhwāl are ascribed by the people to the Katuria rāj.

Two large villages near Almora are called Katyār and Katārmal.-Yours obediently,

Great Bealings, Woodbridge.

Chas. F. Oldham.

November 23, 1897.

To the Secretary of the Royal Asiatic Society.

\title{
6. Who Found Buddha's Birthplace?
}

Audi alteram partem.

To Professor T. W. Rhys Davids, Ph.D., LL.D.,

Secretary, Royal Asiatic Society of Great Britain and Ireland, London.

Dear Sir,-As long as Dr. Waddell ventilated his grievances in the Indian and English newspapers, I did not think it worth while to take any serious notice of them; but since he has chosen your esteemed Journal as a medium, I owe it to the honour of the Department to which I belong to reply to his egoistical statements made in your Number for July, 1897, pages 644-651. 
1. I flatly deny that I ever received any communication, either direct or through the usual Government channel, fom Dr. Waddell concerning the Nigliva pillar inseription.

2. On the 12th May, 1896, I requested the Goverument of the North-Western Provinces and Oudh to obtain the sanction of the Nepalese Darbar, through the Government of India in the Foreign Department, to an exploration being made of the vast ruius near Nigliva as far as Bhagwanpur (Rummindei).

3. On the 29th August, 1896, the Government of India in the Foreign Department, in its letter No. 1,500 E.B., informed the Resident of Nepal, "it has been decided that, if the Nepalese Darbar grant the necessary permission, Dr. A. Führer, Archaeological Surveyor, North-Western Provinces and Oudh, will be deputed to conduct the explorations."

4. Dr. Waddell says in his letter (page 647 of your Journal): "The Lumbini Grove (the actual birthplace) will be found three or four miles to the north of the village of Nigliva"; whilst I found the Lumbini, the modern Rummindei, just thirteen miles east-east-south of Nigliva, and fully eighteen miles east-east-south of the soulhern gate of Kapilavastu. I leave it to others to decide whether I found the Lumbini Grove and Kapilavastu "at the very spots pointed out by Dr. Waddell."

5. I would refer all those interested in the controversy to my forthcoming "Monograph on Buddha Śakyamuni's Birthplace in the Nepalese Tarai," illustrated by two maps of the ruins of Kapilavastu and the Lumbini Grove, which will shortly be issued as No. xxvi of the New Imperial Series of the Archaeological Survey Reports.

6. It would have redounded to the credit of Dr. Waddell if he had also referred to my letter published in the Athenceum in the beginning of April, 1896, which explains the accidental omission of the reference complained of in the Athenoum of September 28, 1895.

On this subject I would like to subjoin copy of $G$. $O$. No. 2,805 W. A., dated Naini Tal, the 6th April, 1896, from 
the Secretary to Government, North-Western Provinces and Oudh, Public Works Department, to the Secretary to the Government of India, Department of Revenue and Agriculture (Archaeology and Epigraphy) :-

"SIR, -I am directed to acknowledge the receipt of Government of India letter, No. 3532/32-11, dated the 31st December, 1895, relative to the complaint by Mr. Stanley Lane Poole of the incorporation, without acknowledgment, in the Report of the Moghal Architecture of Fatehpur Sikri, of certain matter taken from the Introduction to his 'Catalogue of the Moghul Coins in the British Museum.' (2) With reference thereto, I am to state that Dr. Führer did not intentionally commit the plagiarism complained of, as in supplying Mr. Smith with the introduction printed on pages $\mathbf{x} \nabla$ to xix of Part $I$ of the Report in question, it was distinctly stated in a footnote that the short introductory chapter on Akbar's life and character was based in the main points on Dr. Stanley Lane Poole's Introduction to his 'Catalogue of the Coins of the Moghul Emperors in the British Museum,' pages $i$ and $x i$ to xrii. The original manuscript has been submitted for the Lieutenant-Governor's inspection and contains the note. But in preparing the matter for the press, the explanatory note was omitted by Dr. Führer's copyist. The omission was unfortunately not observed by Dr. Führer himself in passing the final proofs. An extract from that officer's letter ${ }^{1}$ on the subject is enclosed for the information of the Government of India."

Lucknow Museum. Yours faithfully, September 14, 1897.

$$
\text { A. Führer, Ph.D. }
$$

\section{Note to above Letter.}

In Dr. Führer's above attempted reply to my letter, he adduces as his proofs merely one fragmentary extract (in his para. 3) from an official letter. This official letter, however, as is evident from its fuller form (given by himself in a letter, under the same heading, to the Pioneer of

$$
1 \text { No. } \frac{\text { A.S. }}{49} \text {, dated 14th March, } 1896 .
$$


October 29, 1897, of which I send a copy for record), expressly refers to quite a different subject altoyether, namely, the excavation of a tomb by the side of the edict-pillar at Nigliva, Nothing is mentioned in that correspondence whatever about the subject of Buddha's birthplace, as this, indeed, was my research, and that long-lost site lay several miles distant from the site of the proposed excavation of the tomb referred to in Dr. Führer's letters.

In reply to his bald para. 1-It will be noted that in the fuller version of his letter, in "categorically denying" receipt of my letter of August, 1893, he says "in 1893, at which date this (Nigliva) pillar was not even known." Yet the notice of this discovery went the rounds of the newspapers in the Spring of 1893, and in Dr. Fuhrer's own printed report for that year (Annual Rept. of the Arch. Surveyor, N.W. Provs., for 1893-4) he himself records it in para. 22 in the following words: "The new Asoka edicts, which were discovered in March, 1893, by Major Jaskaran Singh, of Balrampur." But perhaps Dr. Führer will "categorically deny" that he ever wrote this report, which he has now so completely forgotten. Thus, also, has he doubtless forgotten my two letters; for it is too great an improbability to believe that both these letters never reached him.

As to the quibble in para. 4, it must be remembered that the precise geographical position of the birthplace has not yet been fixed. As Dr. Führer has visited the spot, he might have given us a more intelligible direction than "east-east-south," whatever that may mean. It appears to lie some miles to the east of Nigliva, but we must await a competent survey to fix it. The important indications which I offered, when I started this research, were, that the spot lay certainly within a few miles of this Nigliva pillar, and" that search ought to be made for it there, especially in the directions given by the ancient pilgrims-namely, according to the Chinese version, about " $30 l i$ to the $\mathrm{S} . \mathrm{W}$. and thence $50 l i$ to the N.", and according to the libetan, "one morning and balf a day's journey" to 
" the north-east," as detailed in my original paper. Everybody knows that the Oriental estimate of distance and direction is only approximate at the best. But my central fact remained, that the long looked-for spot lay certainly within a few miles of the Nigliva pillar, somewhat in keeping with the pilgrims' indications, and had only to be searched for to be found.

In his last remaining paragraph, 6 (para. 2 carefully abstains from quotation, though even that letter makes no reference to Buddha's birthplace), he refers to his explanation of the Lane-Poole incident. I had not seen this explanation; but he still "owes it to the honour of the Department to which he belongs" to explain the much graver charges of a similar kind made in the Pioneer of September 22 in regard to his "Monograph" on Christian Tombs in the NorthWestern Provinces.

It is somewhat amusing, after all that Dr. Führer has claimed in regard to this discovery, to find that not only did he not initiate that research, but he had nothing to do with the local discovery of the spot, not even with the unearthing of the famous edict-pillar there, which fixed the spot beyond all doubt. This digging was done by the Nepalese officials in response to my letter to the Grovernment of India; and we learn from the authoritative account by $\mathrm{Mr}$. V. Smith (Journal, p. 618) that Dr. Führer did not arrive on the scene until some time after the extensive excavations had been completed, and when little else was left to be done than to take a copy of the inscriptions.

Thus, the fact of my having initiated and formulated the research in question, which led to a discovery which has been declared by the Oriental Congress to be "one of the most important Indian archaeological discoveries of the century," remains wholly untouched, and is sufficiently vouched for by the official documents which I have already published in this Journal.

December 19, 1897.

L. A. WADDELL.

[The Council have decided that this discussion must now close.] 